UDC 372.881.111.1

DOI https://doi.org/10.24919/2308-4863/40-2-43

Natalia NIKITINA,
orcid.org/0000-0002-1867-0294
Lecturer at Technical English Department № 2
National Technical University of Ukraine "Igor Sikorsky Kyiv Polytechnic Institute"

(Kyiv, Ukraine) nikitinafree@gmail.com

Svitlana BUGA, orcid.org/0000-0001-9609-2867

Lecturer at Technical English Department № 2

National Technical University of Ukraine "Igor Sikorsky Kyiv Polytechnic Institute"

(Kyiv, Ukraine) jabubi21@gmail.com

\title{
TERMINOLOGY IN ESP TEACHING
}

The article considers the professional terminology English teaching to students of technical specialties. Professional terminology is the main, working vocabulary in the professional communication of engineers of any specialty. Strategies and methods of teaching terminology were determined on the basis of a survey conducted among students of the educational level "Bachelor" and "Master". In addition, special attention is paid to methods of online professional terminology teaching and using digital technologies in the classroom. The survey shows that professional terminology in English is used in classes in professional subjects by teachers who teach their subjects in Ukrainian. In addition, the survey found that some classes in professional subjects are already conducted in English. In order for students to be able to attend such classes and receive learning information, their level of English must be appropriate. Moreover, in order to understand the subject in English, they need to know the terminology in English. The article provides an overview of online tools and platforms that should be used in teaching terminology in English. An analysis of the capabilities of these tools and what tools are suitable for training different types of speech activities. The tools for each type of speech activity in teaching terminology in English are listed: for online acquaintance and memorization of new terminology - some online resources, for practice and consolidation - others, etc. A very important aspect discussed in this article is the use of these tools in online or distance learning. Nowadays the main part of learning takes place in distance or mixed format, learning terminology in English is online, or using digital technologies, becomes very relevant. Options for presenting material on the study of terminology in English for each level of the educational process (bachelor and master) and for training different types of speech activities are considered.

Key words: terminology, types of speech activity, English for specific purposes, technical texts, online and distance learning, level of English language proficiency.

Наталя НІКІТІНА, orcid.org/0000-0002-1867-0294 викладач кафедри англійської мови технічного спрямування № 2 Начіонального технічного університету України «Київський політехнічний інститут імені Ігоря Сікорського» (Київ, Україна) nikitinafree@gmail.com

Свімлана БУГА, orcid.org/0000-0001-9609-2867 викладач кафедри англійської мови технічного спрямування № 2 Національного технічного університету України «Київський політехнічний інститут імені Ігоря Сікорського» (Київ, Україна) jabubi21@gmail.com

\section{ТЕРМІНОЛОГІЯ У ВИКЛАДАННІ АНГЛІЙСЬКОЇ МОВИ ПРОФЕСІЙНОГО СПРЯМУВАННЯ}

У статті розглянуто навчання професійній термінології англійською мовою студентів технічних спеціальностей. Професійна термінологія є основною, робочою лексикою в професійному спілкуванні інженерів будь-якої спеціальності. На основі опитування проведеного серед студентів освітнього рівня "Бакалавр» та «Магістр» були визначені стратегї̈ та методи навчання термінологї̈. Крім того, особлива увага приділяється 
методам навчання професійній термінологї̈ он-лайн та з використанням цифррових технологій на заняттях. Проведене опитування показує, що професійна термінологія англійською мовою використовується на заняттях з профільних предметів викладачами, котрі викладають свої дисиипліни украӥнською мовою. Крім того, результатами опитування було виявлено, що деякі заняття з професійних предметів вже проводяться англійською мовою. Для того, щоб студенти мали можливість відвідувати такі заняття та сприймати на них навчальну інформацію, рівень їх англійської мови повинен бути відповідним. Більще того, для того, щңоб розуміти сам предмет англійською мовою, треба володіти термінологією саме англійською мовою. У статті зроблено огляд онлайн-інструментів та платформ, котрі доцільно використовувати у навчанні термінологіі англійською мовою. Проводиться аналіз можливостей ичих інструментів та які саме інструменти підходять для тренування різних видів мовленнєвої діяльності. Перераховуються інструменти для кожного окремого виду мовленнєвої діяльності у навчанні термінологї̈ англійською мовою: для ознайомлення та запам'ятовування нової термінологї - одні онлайн-ресурси, для практики та закріплення - інші і т.д. Дуже важливим аспектом, розглянутим в даній статті, є використання цих інструментів в он-лайн чи дистанційномунавчанні. Ураховуючи, щчо на даний момент основна частина навчання відбувається в дистаниійному або зміманому форматі, навчання термінології англійською мовою саме в онлайн-режимі, або з використанням ичифрових технологій, стає дуже актуальним. Розглядаються варіанти подачі матеріалу з вивчення термінології англійською мовою для кожного рівня освітнього процесу (бакалавр та магістр) та для тренування різних видів мовленнєвої діяльності.

Ключові слова: термінологія, види мовленнєвої діяльності, англійська мова професійного спрямування, технічні тексти, он-лайн та дистанційне навчання, рівень володіння англійською мовою.

In today's pandemic world online or distant learning becomes more and more urgent. Most Universities of Ukraine have the distant form of education. Any higher educational institution had to transform its teaching into the virtual world. The task is the same - to prepare the educated, highly qualified professionals with deep knowledge of the subject, highly experienced practical skills and conclusively the knowledge of foreign language (at least one). In this situation foreign language plays a vital role due to the different possibilities of attending various international conferences, seminars, webinars, etc. Moreover, there are a lot of different courses held by famous universities in the open access. The online Coursera platform proposes numerous courses on almost any subject or topic. The language of these courses is English. The Erasmus + program gives an opportunity to students to have a useful studying program in the University abroad. For all of these courses and programs the obligatory requirement is English language on B2 level. Students chose the courses which are mostly correspond to their specialty, hence the second, more detailed requirement is the knowledge of professional-oriented terminology.

The aim of the work is to identify the necessity of terminology learning in English, the students' acquaintance with the ESP terminology and the methods of its teaching. Each specialty has its own terminology and it should be given in the most appropriate way.

The professional-oriented terminology is the key factor in ESP teaching. ESP terminology embraces words which are mostly used in this professional sphere. In most cases, one English word (not only term) can have different meanings, and only some of them are terms. The perfect example of such situation is the word "scale". It is a term in biology which means "each of the small, thin horny or bony plates protecting the skin of fish and reptiles, typically overlapping one another". In geometry and some other fields it is "a ratio of size in a map, model, drawing, or plan". In metallurgy it is "a coating of oxide formed on heated metal". All of them are independent terms and metallurgists don't use it with the meaning of biological term. There are a lot of such examples and they emphasise the topic of this work.

There are a lot of works and articles describing terminology teaching and learning. Moreover, there are courses on terminology processing (Sager, 1990) which show the history, structure, implementation of the terminology. H. Picht published several books on terminology (Pitch, 1985) itself and on its training (Pitch, 1997). Fundamental, volumetric, useful works dedicated to the terminology are (Cabre, 1999, Alcina, 2011). The important role of terminology teaching was deeply described by (Gomez-Moreno, 2019: 117-120). "Unfortunately, while general-vocabulary teaching has been a main topic of research of across all levels of education, terminology (i.e. specialised vocabulary) instruction has traditionally focused on undergraduate and postgraduate courses, with relatively scarce attention to secondary education" (Gomez-Moreno, 2019). I.Sikorsky "KPI" has the subject 'Terminological system of the Ukrainian language'. It helps students to systemise, study and correctly apply terminology of their specialty. Each of these works helps understand the essence of the term (meaning, use, origin, etc.), its structure and appropriate use, works on terminology teaching explain how to use and correctly translate the terms into foreign language. To sum up the information obtained from the mentioned literature and sources, to understand the terminology in English we should initially understood it in native language and then systematically study and use it in foreign language. 
The main question in terminology teaching is when to start. Certainly, students know general terminology in native language at the very beginning of the study. But it can be inconvenient to learn professionally-specialised terminology on the first year of Bachelor level of studying if they don't know either term, or its meaning. On the other hand, it would be late to start studying English terminology on the first year of Master degree. Everything must be given step by step in accordance with the syllabus. At this point it is very important to co-work, consult and discuss the students' level of professional-oriented subjects' knowledge with the teachers or lectors of these subjects.

First year technical students of Bachelor degree at I. Sikorsky KPI study general-technical subjects. English lessons should cover general terminology of engineering, there can be topics covering history of engineering, early discoveries, innovators, etc. Second and third courses of Bachelor degree start to study professional subjects and have initial practical lessons. It is the perfect time for learning terminology in English in full, students have the strong background and can not only translate the term but also understand and explain it.

Fourth course of Bachelor degree is the time of students' scientific work. They start to write the diploma work; hence they search for specific specialty-related information. Most of updated information on the latest discoveries or innovations is given in English. Generally we find the information by the key words and in the case of any scientific search they are terms. So, on this stage it is absolutely necessary to know the related terminology in English. Students of Master degree students continue their scientific work making it deeper and wider. On this stage the terminology is studied in comparison (compare close terms and difference between them), in peculiarities of use, etc.

Questionnaire results. The questionnaire was carried out between students of Bachelor and Master degree at the E.O. Paton Institute of Materials Science and Welding. Forty three students of different courses of studying took part in the questionnaire. To the question "Do you know the professional-related terminology in English" $72,1 \%$ of students gave the positive answer, 9,3\% - negative answer and $18,6 \%$ "difficult to answer". Considering the question, negative answers were given mostly by junior students $(8,2 \%$ are students of the first and second course students of Bachelor degree, the rest 1,1\% by students of the third and fourth courses). It confirms the idea of students' deep terminology acquaintance in English on the second part of bachelor studying.

How often do you read the professional-related information in English - only 2,3\% of students answered "always" (it is the only representative of the second course of master degree). Most of the students answered "sometimes" and the amount constitutes $88,4 \%$, it means they can't eliminate the foreign language information in their scientific work. 9,3\% of students answered "never" to this question. This option also shows the ability to find the information in English which is widely used by technical students.

There were three alternatives (yes; no; sometimes) in the question "Do you use the professional-related information in English in your scientific work". Most part of the students replied "sometimes", 46,5\%. It identifies the low level of foreign terminology level which complicated the information search. They are mostly students of first and second courses of Bachelor degree. Among these students the widespread answer is "no" $-30,2 \%$, but it can be explained by the absence of the scientific work or research on this stage of education. The elder students answered "yes" $23,3 \%$. Any question on scientific work is applied to the student of Master degree or at least the students of third and fourth courses of Bachelor degree. But the initial preparation to scientific research should start at the very beginning of the studying.

Nowadays more and more disciplines are taught in English. There are even disciplines in timetable which students can choose and have lessons in English. That is the reason why $51,2 \%$ of students gave positive answer to the question'Do you have professional disciplines in English. This number embraces students of all courses. Students chose such disciplines in English mostly in case when they have sufficient English level and acquaintance with terminology and subject. It is a perfect opportunity for students to increase their English level and get knowledge in international language.

Considering professional disciplines, it is important to mention the terminology used by teachers on these lessons in English. There are a lot of adoptions and cognates, most of the terms are the same in different languages that's why they are widely used even in Ukrainian teaching. But there are sometimes situations where teachers use terms in English for better explanation of the material. Sometimes teachers give the auxiliary material in English, for example presentation is in English and the explanation is in Ukrainian. Slides generally contain figures with numbers and termi. Here we have the next question of the questionnaire with the predicted results. Do your teachers use English terminology on the lessons - 90,7\% of students confirmed and 9,3\% gave the negative answer (most of them are students of the first and second course of bachelor degree). This option shows the necessity of professional terminology knowledge in English. 
To sum up the results of the questionnaire, students of technical specialties should know the professional terminology starting with the second course of bachelor studying, when the have already known the peculiarities of their specialty in native language and can start to get, perceive and use this information in English. They more often use the information in English on the higher courses, but to this moment the terminology in English should be learned. On the first courses there should be the introduction to the specialty in English and the initial work with the simplest, widely used terminology. The most active students of this questionnaire were of the first, third and fourth courses of bachelor degree and students of the first course of master degree were also rather active. It can be used as a perfect background for further investigation, involving students of the second courses (bachelor and master degrees).

There are a lot of methods and ways of English terminology teaching and we will consider some of them, which can be used in offline and online teaching. The simplest way of terminology teaching is the list of words with the translation or explanation in English. But without context or practical use these words become passive and such methods don't give the practical results. The basic instrument in technical English teaching is text. Nowadays, in modern technological world it also can be video material, where record is used as the main source of information. In this case it is not a printed text, but audio information with video support (subtitles are the perfect part of printed information). Most of the units in textbooks have pretext tasks, the new vocabulary or terminology is given here (Sections "start here" or "Warming up", etc.), the main exercises based on the text (vocabulary, grammar exercises - "Write", "Use the words", "Complete", "Practise", etc.), and final, summing up tasks ("Write a composition", "Prepare a report", "Think about", etc.). The Video material can be supported by the same types of exercises.

Generally, pretext exercises give the new vocabulary or terminology which will be used, learned and practiced in the unit or topic. Specific, professional terminology can be studied on professionally-oriented texts or videos, hence there are few English textbooks which absolutely cover topic of study. Pretext exercises with terminology are based on the text or video. On the first years of studying these topics are general and non-specified: history of engineering, history of the science, innovators, etc. There are terms which most of the students already know and they just learn the equivalents in English.

For the students of the third and fourth courses the texts are more professionally oriented and video describes special peculiarities of the processes studied on the main subjects in native language. The terms differ from those for beginners and are the terms of the specialty. They are the names of the processes, the names of the initial materials, the final products, etc. Moreover, it is the most saturated part of terminology studying, because students start not only to study but to work with the materials on their practical lessons or laboratory works. So, to start reading the text about, for example, open-hearth furnace, students should learn names of its parts, structure and operations in English (instead of open-hearth furnace, there can be any other equipment or process). Master degree students have more detailed or specialized texts or video material and having deeper knowledge on specialty can have the warming-up tasks like "Explain the meaning of the terms", "Guess the meaning of the terms", etc.

The tasks in the pretext exercises must differ according to the students' English level and course of studying. If the information is in video format, the tasks can differ a little - "You are going to watch a video about any item, find, translate, guess or explain the meaning of the term", etc. Use of video material (even in offline teaching) gives more opportunities to explain the meaning of the term. Of course, teachers of English language know the meaning and translation of all terms they use in teaching, but the English explanation by the native speaker and the professional in this field is much better.

Before starting any new lexical topic, terms must be given with the excellent translation, explanation and structure. Structure means that terms should be presented in order of appearance in the main material or according to the complexity (start with the simple general terms and then enumerate to the more specific). If information is given in video format, terminology must be presented before watching the video for students of all levels to have the comprehension of the topic.

The main part is the text or video material. All exercises directed on the general understanding of the information, use of the terms mentioned in the pretext section, there also can be grammar exercises. It is also very important part of terminology studying. Isolated terms must be used in sentences which are grammatically correct. In this section terms are practiced in use by template. Exercises are "Choose the correct term to each sentence", "Make sentences using correct terms", "Match the terms with their explanation", etc. In this section students practice the use of the terms and their meaning. All these exercises should be based on the information from the text or the video, hence students memorise the terms, their meanings, ways of use and grammar peculiarities. 
The summarising part of the exercises covers the tasks where students can use terms in their own way. "Speak about...", "Describe the ....", "Prepare a short information about...", etc. The level of the task (whether the general information on the history for the students of the first courses, or the detailed information on the specific term for the students of master degree) depends on the course of studying. Here students should apply all the obtained information and knowledge on the topic.

Online devices and tools for terminology teaching. Studystack and Quizlet are online instruments for creating flashcards with the necessary terminology or vocabulary. They are perfect for the pretext exercises to practice and learn new terms. There are English terms on the one side of the card and translations or explanations on the other one. They can be used on the online lesson for practicing with the group or students can use them individually.

For the main part of exercises there are a lot of online instruments and tools. It can be Google class, Classtime, Nearpod, Peardeck, Moodle, Telegram, etc. Google instruments cover the most part of different types of exercises and it is most widely used. There are presentations for teaching and giving information, jamboard - useful devise for interactive work on the lesson. Students can move cards or sticks with terms to the cards with their definition. Moreover, students can make their own cards in jamboard online writing the correct or possible answers, join the link to some interesting information in Internet, etc. There can be exercises on writing, listening, matching, translation, etc. Nearpod has different types of exercises, they can be formed in game forms, there can be quizzes (giving correct answers, students climb the mountain, for example), there are a lot of interactive forms. One more interesting feature of this tool is the possibility to give the written or voice-recorded answers. The exercises can be developed for team work that motivate and help students to do the task better. Peardeck is the presentation platform for making interesting, bright, fascinating slides for Google. Moodle and Classtime are perfect to control the progress. There are a lot of variants for making exercises to check different types of terms comprehension. They can be used as the part of home work to imprint the online studied material. Furthermore, in premium version of Classtime it is possible to make challenges and involve students online. There are different games where students have to accomplish different tasks to win, obtaining and practicing topic, terms and material. Students enjoy quick quizzes in the Telegram. They are easy and quickly developed and can be used on any stage of terminology studying.

Today there are a lot of other online tools and all of them should and must be used in online English teaching. The most important feature of any of these tools is that teacher does not need to check the answers, programs make it automatically. Of course, written works are checked by the developer or teacher, but in most cases for terminology teaching tasks with automatic control are used.

According to the questionnaire English terminology is used by students from the very beginning of their studying. It is important to teach them the corresponding terminology in the corresponding time. At the end of Bachelor degree they should have sufficient professional-related vocabulary and terminology to make a scientific search and accomplish the diploma project. Masters must be taught the English professional terminology and its description.

To become highly-skilled professionals, students should obtain deep knowledge of professional subjects supported by sufficient level of ESP. Terminology is the key vocabulary in scientific work of any sphere or branch of engineering. There are a lot of online platforms and instruments for offline or online English terminology teaching. For each level different appropriate instruments can be chosen, developed and used. Moreover, they can be chosen for different types of tasks (for instance, Google instruments for reading, Nearpod for matching, Classtime for writing, etc.) and for different way of teaching - offline or online. Teacher has a lot of opportunities appropriate for him and his students for excellent terminology teaching in English.

\section{BIBLIOGRAPHY}

1. Alcina A. Teaching and Learning Terminology: New Strategies and Methods: Amsterdam : John Benjamins, 2011. $157 \mathrm{p}$

2. Cabre M. Terminology: Theory, Methods and Applications: Amsterdam : John Benjamins, 1999. 248 p.

3. Gomez-Moreno P. O. Teaching and learning terminology in secondary education: Towards specialisation through language. Porta Linguarum. 2019. № 31. P. 117-130.

4. Picht H. "Aspects of terminology training”, in S. Wright and G. Budin (eds.), Handbook of Terminology Management: Basic Aspects of Terminology Management : Amsterdam: John Benjamins, 1997. 372 p.

5. Picht H., Draskau J. Terminology: An Introduction : University of Surrey, Department of Linguistic and International Studies, 1985. 265 p.

6. Sager J. C. A practical course in terminology processing : UMIST, Manchester: Amsterdam: John Benjamins Publishing, 1990. $258 \mathrm{p}$. 


\section{REFERENCES}

1. Alcina, A. (2011). Teaching and Learning Terminology: New Strategies and Methods. Amsterdam: John Benjamins.

2. Cabre, M.T. (1999). Terminology: Theory, Methods and Applications. (Vol.1). Amsterdam: John Benjamins.

3. Gomez-Moreno P. U. Teaching and learning terminology in secondary education: Towards specialisation through language. Porta Linguarum 31, enero 2019.

4. Picht, H., Acuna-Partal, C. (1997). "Aspects of terminology training”, in S. Wright and G. Budin (eds.), Handbook of Terminology Management: Basic Aspects of Terminology Management. Amsterdam: John Benjamins.

5. Picht H., Draskau J. (1985). Terminology: An Introduction. University of Surrey, Department of Linguistic and International Studies, 1985.

6. Sager J.C. (1990). A practical course in terminology processing. Amsterdam: John Benjamins Publishing. 